\title{
Putting Privateers in Their Place: The Applicability of the Marque and Reprisal Clause to Undeclared Wars
}

\author{
C. Kevin Marshall $\uparrow$
}

Few constitutional issues have so consistently held the attention of scholars and politicians over the last thirty years as the distribution of war powers between Congress and the President. While the Vietnam War and the War Powers Resolution provided the initial sparks, ${ }^{1}$ Presidents since then have been more than forthcoming in offering new fuel for the war powers debate, particularly President Reagan. ${ }^{2}$ Not only have presidents carried out acts one could consider "war," such as invading Grenada, Panama, or Iraq, but they also have assisted groups seeking to topple foreign governments, such as Nicaragua's, often without notifying, much less receiving permission from, Congress. These "little wars" and covert actions have ignited yet another flame of the post-Vietnam debate. ${ }^{3}$ Several scholars, led by Professors Charles Lofgren and Jules Lobel, have turned to the long-neglected power of Congress to grant letters of marque and reprisal ${ }^{4}$ to support congressional authority over all military actions short of declared war.

† B.A. 1994, Middlebury College; J.D. Candidate 1998, The University of Chicago.

' See Peter J. Spiro, Old Wars /New Wars, 37 Wm \& Mary L Rev 723, 737 n 31 (1996) (Before Vietnam War, "there was little ... scholarly commentary" on war powers. War was a "turning point" in academic discussion of issue.).

${ }^{2}$ See, for example, David Locke Hall, The Reagan Wars: A Constitutional Perspective on War Powers and the Presidency 135-269 (Westview 1991) (considering action in Lebanon, invasion of Grenada, bombing of Libya, and escorting of Kuwaiti shipping during the Iran-Iraq war); Gary M. Stern and Morton H. Halperin, "Covert" Paramilitary Action and War Powers, in Gary M. Stern and Morton H. Halperin, eds, The U.S. Constitution and the Power to Go to War: Historical and Current Perspectives 149, 156 (Greenwood 1994) (evaluating Reagan Administration's actions in Afghanistan, Nicaragua, and Angola).

${ }^{3}$ See Jules Lobel, "Little Wars" and the Constitution, 50 U Miami L Rev 61, 61 (1995) (defining "little wars" as "small military interventions and quick strikes, such as the Libyan bombing, the Grenada and Panama invasions, and the recent bloodless invasion of Haiti"); Jules Lobel, Covert War and Congressional Authority: Hidden War and Forgotten Power, $134 \mathrm{U} \mathrm{Pa}$ L Rev 1035, 1039-41 (1986) (arguing for congressional control over use of "proxy armies" and other forms of "CIA paramilitary operations against foreign governments," such as those used in Nicaragua). An alternate term for "little war" is "lowintensity conflict." Mark T. Uyeda, Note, Presidential Prerogative Under the Constitution to Deploy U.S. Military Forces in Low-Intensity Conflict, 44 Duke L J 777, 777 (1995).

- US Const, Art I, \& 8, cl 11. 
A proper understanding of letters of marque and reprisal, derived from closely examining their use in the American Revolution, shows that these scholars are overreaching. Letters of marque and reprisal were government authorizations to private shipowners to seize property of foreign parties, usually ships or property from ships. An essential feature of letters of marque and reprisal was the financial independence of those holding them-a critical characteristic in light of the importance of Congress's power of the purse, and one that is absent from the modern examples provided by the scholars who appeal to the Marque and Reprisal Clause as a basis for vast congressional authority. The Clause acquires modern relevance, if at all, only when the executive fights independently of Congress's power of the purse.

Part I of this Comment surveys the increasing scholarly attention to the Marque and Reprisal Clause, emphasizing the work of Lofgren and Lobel. Part II first lays out the law that governed those enterprising Americans who received letters of marque and reprisal during the Revolution. It then explains the three historical characteristics that created those Americans' financial independence, making special treatment in the Constitution necessary: the focus on commercial rather than military exploits, the absence of governmental support, and the lack of governmental supervision except for the prize courts, which not only supervised them, but also granted the law-abiding title to (and thus the critical income from) the ships and other property they seized. Part III, emphasizing the relationship between Congress's power of the purse and these financial aspects, applies Part II to show how the recent interpretations of the Marque and Reprisal Clause rest upon mistaken analogies.

\section{THE REVIVAL OF THE MARQUE AND REPRISAL CLAUSE}

While it might appear that the Marque and Reprisal Clause belongs in the dustbin of history where it has rested for over a century and a half, such an appearance would be deceiving. Although the United States has not issued letters of marque and reprisal since the War of $1812^{5}$ and has not considered doing so since Andrew Jackson's presidency, ${ }^{6}$ and although an international treaty has banned them since $1856,{ }^{7}$ a growing group of

5 Lobel, 134 U Pa L Rev at 1045 (cited in note 3). The Confederacy, however, relied on them during the Civil War. Id; Fritz Grob, The Relativity of War and Peace: A Study in Law, History, and Politics 239 (Yale 1949).

6 See Louis Fisher, Presidential War Power 163-64 (Kansas 1995); Grob, Relativity of War and Peace at 239 (cited in note 5).

7 This was the Declaration of Paris. The United States did not ratify it, but has 
scholars invokes the Clause to open a new front in the ongoing battle over war powers. They argue that the President must gain congressional approval before initiating any military actions, except in extreme emergencies. This requirement results from a convenient synergy between Congress's powers under the Marque and Reprisal Clause and the Declare War Clause: ${ }^{8}$ the former covers all little wars, and the latter covers the big ones, so they claim.

In 1972 Charles Lofgren made the first serious effort to apply the Marque and Reprisal Clause to the modern debate. ${ }^{9}$ Lofgren largely builds his argument on various treatises of the seventeenth and eighteenth centuries, ${ }^{10}$ although he concedes that knowledge of them "was sometimes superficial" in the framing period." The treatise-writers distinguished between "perfect" war, which was declared, and "imperfect" war, which was not declared and which was closely associated with reprisals. ${ }^{12}$ States could authorize specific reprisals, in which private parties seized the property of a foreigner to redress some specific private injury, and general reprisals, in which a state either used its own forces or authorized private parties to vindicate some national indignation. ${ }^{13}$

Lofgren notes that the uses, and therefore the meaning, of letters of marque and reprisal had changed over the centuries

largely upheld its ban on privateering. Edgar Stanton Maclay, A History of American Privateers xxiii (Appleton 1899).

${ }^{8}$ Art I, \& 8, cl 11 of the Constitution grants Congress power "[t]o declare War, grant Letters of Marque and Reprisal, and make Rules concerning Captures on Land and Water."

9 Charles A. Lofgren, War-Making Under the Constitution: The Original Understanding, 81 Yale L J 672 (1972). Lofgren laments that "recent students of the war-making issue" have neglected the Marque and Reprisal Clause. Id at 680 n 28.

${ }^{20}$ Id at 689-94, citing, among others, Hugo Grotius, The Rights of War and Peace (1625); Emmerich de Vattel, The Law of Nations (1758); and Jean Jacques Burlamaqui, The Principles of Natural and Politic Law (1752). See also W. Taylor Reveley III, War Powers of the President and Congress: Who Holds the Arrows and Olive Branch? 54-55 (Virginia 1981) (briefly noting both the theorists and history through end of French and Indian War).

" Lofgren, 81 Yale L J at 689 n 74 (cited in note 9).

${ }^{12}$ Id at $692-93$.

${ }^{13}$ Id at 693 . Other scholars disagree with Lofgren's suggestion that all reprisals fall within the phrase "letter of marque and reprisal." Compare id at 696 ("The [Clause] [ ] could easily have been interpreted ... as a kind of shorthand for vesting in Congress the power of general reprisal outside the context of declared war."), with Francis D. Wormuth and Edwin B. Firmage, To Chain the Dog of War: The War Power of Congress in History and Law 37 (SMU 1986) ("[T] he only form of reprisal assigned to Congress by the Constitution is the issuance of letters of marque and reprisal."). See also John C. Yoo, The Continuation of Politics by Other Means: The Original Understanding of War Powers, $84 \mathrm{Cal}$ L Rev 167, 250-51 (1996) (Clause "does not appear" to cover "all forms of imperfect war."). 
and were still changing at the time of the Founding. ${ }^{14}$ By the first half of the 1700s, specific reprisals had "virtually disappeared" and would have been considered "outmoded" by the time of the Founding, while general reprisals, whether by public or private forces, continued..$^{15}$ Lofgren tentatively concludes that the most likely understanding at the Founding was that the Clause granted Congress "whatever war-commencing power was not covered by the phrase "to declare war."'16 Putting the two clauses together, it follows that Congress holds "nearly complete authority over the commencement of war."17

The leading current advocate of applying the Marque and Reprisal Clause to all modern military actions short of declared war is Jules Lobel. ${ }^{18}$ In urging a "modern day analogy," he emphasizes covert actions, proclaiming that "the covert action of today is the marque and reprisal of yesterday." ${ }^{19}$ Both, he claims, involve private rather than public individuals and forces, and both involve "hostilities against other nations," usually when no declared war exists. ${ }^{20} \mathrm{By}$ "covert action," he generally means any action in which the Central Intelligence Agency (CIA) finances,

${ }^{14}$ Lofgren, 81 Yale L J at 693-97 (cited in note 9). See also Grob, Relativity of War and Peace at 238-39 (cited in note 5) (noting that while Founding is obscure on letters of marque and reprisal, practice suggests the proper meaning).

${ }^{15}$ Lofgren, 81 Yale $L J$ at 693-94 (cited in note 9). For a survey of privateering and letters of marque and reprisal from the time of King John to the Revolutionary War, see Gardner Weld Allen, Massachusetts Privateers of the Revolution 3-63 (Mass Hist Socy 1927). On the decline in the 1600 s of reprisals for private claims, see id at 9 . For an account of American privateering before the Revolutionary War, see id at 9-13, and John Franklin Jameson, Privateering and Piracy in the Colonial Period: Illustrative Documents (Macmillan 1923).

${ }^{16}$ Lofgren, 81 Yale L J at 697 (cited in note 9).

${ }^{17}$ Id at 700 .

${ }^{18}$ Lobel, $134 \mathrm{U}$ Pa L Rev 1035 (cited in note 3). Many commentators in addition to Lobel and Lofgren advocate a strong Marque and Reprisal Clause, most of them relying on one of these two authors, or both. See, for example, Reveley, War Powers at 54-55, 6364 (cited in note 10); Edward Keynes, Undeclared War: Twilight Zone of Constitutional Power 23, 37 (Penn State 1982); Mark J. Yost, Note, Self Defense or Presidential Pretext: The Constitutionality of Unilateral Preemptive Military Action, 78 Georgetown L J 415, 423 (1989); Fisher, Presidential War Power at 162, 3, 17-20 (cited in note 6); Peter RavenHansen, Constitutional Constraints: The War Clause, in Stern and Halperin, eds, Power to Go to War 29, 30-31 (cited in note 2); Gary M. Stern and Morton H. Halperin, Introduction, in Stern and Halperin, eds, Power to Go to War 1, 7 (cited in note 2).

${ }^{19}$ Lobel, $134 \mathrm{U}$ Pa L Rev at 1051, 1041 (cited in note 3).

${ }^{2}$ Id at 1051. Lobel more recently extended this comparison, arguing that the Marque and Reprisal Clause also requires congressional authorization for "small military interventions and quick strikes, such as the Libyan bombing, the Grenada and Panama invasions, and the recent bloodless invasion of Haiti." Lobel, $50 \mathrm{U}$ Miami L Rev at 61 (cited in note 3). 
trains, organizes, or leads foreign military groups, usually to undermine a disliked government or to attack terrorists. ${ }^{21}$

Lobel defines "letters of marque and reprisal" loosely rather than technically, and uses this loose definition to justify his broad claims. Although he views the phrase as effectively confined by the time of the Founding to general letters issued to private parties-a view which is common (and correct) ${ }^{22}$-he nevertheless argues that at that time the phrase included "any intermediate or low-intensity hostility short of declared war. ${ }^{p 23}$ It meant "authorizations usually given to private merchantmen to go out and fight the enemy."24

These scholars' arguments ${ }^{25}$ hinge on the original meaning and history of the Marque and Reprisal Clause, yet they omit the most important ingredient of that meaning and history. None of the commentators considers the use of letters of marque and reprisal in the period with which the Framers would have been most familiar-the American Revolution. ${ }^{26}$ The Founding itself

${ }^{21}$ Lobel, $134 \mathrm{U}$ Pa L Rev at 1036 n 9 (cited in note 3).

${ }^{24}$ See Keynes, Undeclared War at 23 (cited in note 18); Abraham D. Sofaer, War, Foreign Affairs, and Constitutional Power: The Origins 271 (Ballinger 1975); Fisher, Presidential War Power at 162 (cited in note 6). See also John Hart Ely, War and Responsibility: Constitutional Lessons of Vietnam and its Aftermath 66-67 (Princeton 1993). Part II explains the various private aspects of those who had letters of marque and reprisal.

${ }^{2}$ Lobel, $134 \mathrm{U}$ Pa L Rev at 1045 (cited in note 3). Lobel adds that while some writers drew a distinction between letters of marque and letters of marque and reprisal based on whether they were issued in war or peace, and while letters of marque were often distinguished from privateer commissions, treaties of the time tended to refer only generally to "private armed vessels." Id at 1045 n 49.

${ }^{2}$ Lobel, $50 \mathrm{U}$ Miami L Rev at 67 (cited in note 3). As Lobel defines them, letters of marque authorized trading vessels to arm themselves and "attack ships of foreign nations during peace or war," while privateers were armed private vessels authorized by their commissions "to fight in place of or alongside public naval vessels." Lobel, $134 \mathrm{U} \mathrm{Pa} \mathrm{L}$ Rev at 1044 (cited in note 3). As Part II explains, however, it is imprecise to use the words "attack" and "fight," since the goal was to seize goods and make a profit rather than to make war. The claim that privateers fought "in place of or alongside public naval vessels" becomes a lament when one examines practices and attitudes in the American Revolution.

$\therefore$ A few scholars have weighed the above arguments and found them wanting. See Marshall Silverberg, The Separation of Powers and Control of the CLA's Covert Operations, 68 Tex L Rev 575, 581 (1990); Hall, The Reagan Wars at 19 (cited in note 2). The most serious response comes from John Yoo. See Yoo, $84 \mathrm{Cal} \mathrm{L} \mathrm{Rev} \mathrm{at} 167$ (eited in note 13). But his originalist argument for executive initiative and congressional checks via the power of the purse covers war powers broadly and devotes only brief attention to letters of marque and reprisal and none to their use in the Revolution. Id at 250-52.

2 Lobel merely states that "[1]etters of marque were issued during the American Revolution," $134 \mathrm{U} \mathrm{Pa} \mathrm{L} \mathrm{Rev} \mathrm{at} 1044$ (cited in note 3), and briefly discusses the Articles of Confederation, id at 1059. Lofgren notes that the "precise interpretation of the scope of the power" in the time of the Founding depended on "how [Americans in 1787-88] understood the purpose of letters of marque and reprisal," 81 Yale L J at 679-80 (cited in note 9), but he does not discuss how the Revolution affected or revealed that understanding, see id at 693 . 
receives sparse attention, but this is for the understandable reason that the Framers and ratifiers of the Constitution gave the Marque and Reprisal Clause sparse attention. ${ }^{27}$ This sparseness makes historical practice more important for evaluating Lobel's "modern day analogy." The next Part unearths that history.

\section{LETTERS OF MARQUE AND REPRISAL IN THE AMERICAN REVOLUTION}

While current scholars claim that the Marque and Reprisal Clause grants Congress wide war powers, practice during the American Revolution tells a different, more restrained, story. It reveals that letters of marque and reprisal were privately financed, governmentally authorized means of commercial warfare conducted for profit and supervised only after-the-fact. They were not government tools for conquest, revolution, or general mayhem.

The defining characteristic of letters of marque and reprisal was profit and the financial independence resulting from it. ${ }^{28}$ One

Lobel refers briefly to wars and statements in the politically charged 1790s to support his interpretation of the Clause. See Lobel, $134 \mathrm{U} \mathrm{Pa} \mathrm{L} \mathrm{Rev} \mathrm{at} 1046$ (cited in note 3) (various statements from 1793 and later); id at 1061-63 (Neutrality Act of 1793, although noting that neither the Act nor its legislative debates mentions the Marque and Reprisal Clause); id at 1065-69 (Quasi-War with France from 1798 to 1800). See also Sofaer, War, Foreign Affairs, and Constitutional Power at 105-11, 365-66 (cited in note 22) (discussing controversy with France over outfitting French privateers in American harbors and efforts to combat privateering in the Caribbean in the 1810s and 1820s); id at 140-42, 155, 163-64 (discussing various aspects of the Quasi-War).

${ }^{27}$ See Lofgren, 81 Yale L J at 679-80 (cited in note 9). In the first North Carolina ratifying convention, which rejected the Constitution, the Marque and Reprisal Clause was "read without any observation." Id at 683-84, quoting Jonathan Elliott, ed, 4 The Debates in the Several State Conventions on the Adoption of the Federal Constitution 94 (Taylor \& Maury 1854). The ratification debates overall "were little concerned with how the new government would initiate war." Lofgren, 81 Yale L J at 683.

The Clause received only one brief mention at the Constitutional Convention, on August 18, when Elbridge Gerry suggested adding to congressional powers "something [ ] concerning letters of marque, which he thought not included in the power of war." Adrienne Koch, ed, Notes of Debates in the Federal Convention of 1787, Reported by James Madison 478 (Norton 1978). Some have tried to read this as suggesting a desire to ensure congressional power over all uses of American force. See, for example, Reveley, War Pow$e r s$ at 86 (cited in note 10). But see Grob, Relativity of War and Peace at 238-39 (cited in note 5) ("It is not possible to say with what intention the founding fathers wrote [the Clause] into the Constitution since there was no comment or debate as to [its] meaning in the Constitutional Convention."). Grob looks instead to practice. Id at 239-47.

Publius only cursorily mentioned the Clause. Federalist 44 (Madison), in Clinton Rossiter, ed, The Federalist Papers 280, 281 (Mentor 1961). Tangentially related references can be found at Federalist 40 (Madison), id at 247, 250 (capture), Federalist 41 (Madison), id at 255, 256 (absent from discussion of war powers), and Federalist 6 (Hamilton), id at 53,59 (reprisals).

${ }^{23}$ A more precise definition of the relevant terms is necessary even though at the time of the Revolutionary War, people used the relevant terms loosely. See Lobel, $134 \mathrm{U}$ 
can divide this characteristic into three interrelated parts. First, letters of marque and reprisal were more a commercial than a military matter. Private shipowners had commercial goals and a commercial mentality, and they were incompetent in normal war activities. They contributed to the war effort through commercial means-by disrupting British commerce and sustaining American commerce. Second, holders of letters of marque and reprisal paid their own way. They received no government funds; instead they often had to pay the government for supplies or were asked to finance other governmental actions. Third, governmental control over the use of letters of marque and reprisal, to the extent it existed at all, rested in the judiciary and focused on the legality of and title to seized property-the booty or "prize" with which privateers financed their voyages. This Part first examines the law governing privateers during the Revolution, in light of these three characteristics, and then explains each of them in more detail.

\section{A. The Law for Private Ships of War During the American Revolution}

The law that governed privateers and letters of marque during the Revolution demonstrates the three characteristics mentioned above: commercial motives, private funding, and after-the-fact judicial control. While Congress set most of the rules, Massachusetts, which dominated privateering and all things naval during the war, ${ }^{29}$ acted first to authorize private armed ships

Pa L Rev at 1045 (cited in note 3) ("In eighteenth century America, the term "letters of marque and reprisal' ... was used interchangably with the terms reprisal, privateer, and commission ...."). Sometimes they merely spoke of "private ships of war," [Executive] Council [of Pennsylvania] to Pres. Of Congress (Mar 3, 1778), in Samuel Hazard, ed, 6 Pennsylvania Archives 327 (Severns 1853), or "cruizing vessels," Pres. Of Congress to Pres. Wharton [of Pennsylvania] (Mar 21, 1778), in Hazard, ed, 6 Pennsylvania Archives at 378 . A privateer was a private merchant ship authorized by some government and specially refitted for "the sole purpose of hunting down and capturing enemy ships and cargoes." Sidney G. Morse, New England Privateering in the American Revolution 45-46 (unpublished $\mathrm{PhD}$ dissertation, Harvard 1941) (available via WorldCat). A letter of marque was a merchant ship with the primary purpose of trade, but with authority to seize enemy ships that it encountered. The term "letter of marque," however, could refer both to the authorizing letter (equivalent to the privateer's commission) or to the ship. In the former meaning, it was not unusual for someone to say a privateer had received a letter of marque. The line often blurred, and many vessels "embodied the characteristics of both." Id at 45-46, 61-62. See also Gardner W. Allen, 1 A Naval History of the American Revolution 45-46 (Houghton Mifflin 1913) (referring to "letters of marque" that Congress issued "to privateers"). This Comment keeps the terms separate as much as possible, but, like the historians, it emphasizes the privateers. See Allen, Massachusetts Privateers at 13-14 (cited in note 15).

'See William M. Fowler, Jr., Rebels Under Sail: The American Navy During the 
and was one of only two states to do so before Congress acted..$^{30}$ John Adams, a great advocate of privateering during the Revolutionary War, extolled the Massachusetts privateering law as, according to one scholar, "one of the most important documents of the Revolution." 31

But the Massachusetts privateering law is remarkable for its restraint. While Elbridge Gerry's preamble decried the "despotism" of a British government "divested of justice and humanity," and while he invoked Massachusetts's power under its colonial charter to "kill, slay, destroy, and conquer,"32 the powers for private armed ships were merely the following:

[T] he council of this colony ... [may] commission, with letters of marque and reprisal, any person or persons within this colony, who shall, at his or their own expence, fix out and equip, for the defence of America, any vessel, ... and [ ] all such persons so commissioned ... shall have full power, ... to sail on the seas, attack, take and bring into any port in this colony, all vessels offending or employed by the enemy ... and also to retake and bring in ... any vessel or vessels that may be taken from any person or persons by said enemy. ${ }^{33}$

Revolution 54, 73-76 (Scribner's 1976). See also Charles Oscar Paullin, The Navy of the American Revolution: Its Administration, its Policy, and its Achievements 148 (Chicago 1906) (New England was "the backbone" of revolutionary privateering. Massachusetts sent out about one-third of the total number of privateers for the whole war, and Boston was the chief center both for fitting out privateers and for selling prize.); Morse, New England Privateering at 77-78 (cited in note 28). Pennsylvania was the other main source of privateering and letters of marque. Morse, New England Privateering at 46; Fowler, Rebels Under Sail at 74; Paullin, Navy of the American Revolution at 154-55.

${ }^{30}$ Morse, New England Privateering at 33-35 (Massachusetts), $52-53$ (Rhode Island) (cited in note 28).

${ }^{31}$ Paullin, Navy of the American Revolution at 321 (cited in note 29), referring to An Act for Encouraging the Fixing Out of Armed Vessels to Defend the Sea-Coast of America, and for Erecting a Court to Try and Condemn All Vessels That Shall Be Found Infesting the Same, 1775 Mass Acts ch 7 ("Mass Armed Vessels Act"), reprinted in 5 The Acts and Resolves, Public and Private, of the Province of Massachusetts Bay 436 (Wright \& Potter 1886) ("Mass Acts and Resolves"). Morse notes that only a sovereign government could authorize privateers and letters of marque, so the act was effectively a declaration of independence, see Morse, New England Privateering at 47 (cited in note 28) (discussing Congress's debate on granting commissions to privateers), and there was nothing covert about it. See also Paullin, Navy of the American Revolution at 322-23 (cited in note 29) (discussing the Massachusetts law generally).

${ }^{32}$ Mass Armed Vessels Act, 1775 Mass Acts ch 7, Preamble, reprinted in 5 Mass Acts and Resolves at 436-37 (cited in note 31).

${ }^{33}$ Id, 1775 Mass Act ch 7, § 2, reprinted in 5 Mass Acts and Resolves at 437 (emphasis added). Gerry's appeal to the charter was creative but dubious, since one doubts a government would issue a charter allowing a colony to make war against it. Morse, New England Privateering at 34-35 (cited in note 28). 
Thus, privateers paid their own way and aimed to seize British ships, preferably returning them to Massachusetts in one piece. Those receiving commissions had to post a bond, promising to observe the colony's laws and privateering instructions. ${ }^{34}$ The law also set up three courts of admiralty, empowering the judges to call juries and to "have full cognizance of, and power to try the justice of, the capture of any vessel or vessels that shall be taken ...."35 The persons making a capture had to make out a bill describing the ship captured and including "a schedule of the cargo on board her" when captured. If the jury's verdict justified "condemn[ing]" the ship and its cargo, the judge would order everything sold and give the proceeds, minus court costs, "to the captors, their agents or attorneys." ${ }^{36}$

In March 1776, the Continental Congress responded to the wails of suffering merchants by enacting national rules for letters of marque and reprisal. ${ }^{37}$ These rules follow the same pattern as Massachusetts's-emphasizing lawful seizure of British ships and cargo with minimal destruction. Denouncing the British for "wasting, spoiling, and destroying the country, burning houses and defenceless towns, and exposing the helpless inhabitants to every misery," and lamenting Britain's embargo on American trade and authorization of seizure of American goods at sea, Congress authorized all inhabitants of the colonies "to fit out armed vessels to cruize on the enemies" of the colonies. ${ }^{38}$ But Congress limited lawful prize to ships (and their cargoes) belonging to British inhabitants (except "friends of the American cause") if taken by a commissioned ship and "libelled and prosecuted" in any maritime court. ${ }^{39}$ All prizes, after deductions for court costs, went to those capturing the ship. ${ }^{40}$

A few weeks later, Congress created a mechanism for carrying out this new law and drafted instructions for privateers and

\footnotetext{
${ }^{24}$ Mass Armed Vessels Act, 1775 Mass Acts ch 7, $\S 3$, reprinted in 5 Mass Acts and Resolves at 437-38 (cited in note 31).

${ }^{\approx}$ Id, 1775 Mass Acts ch 7, $\S \S 4-7$, reprinted in 5 Mass Acts and Resolves at 438-39.

${ }^{35}$ Id, 1775 Mass Acts ch 7, $\S 8$, reprinted in 5 Mass Acts and Resolves at 439-40. For an overview of the history and development of the Massachusetts privateering law, see Paullin, Navy of the American Revolution at 321-28 (cited in note 29).

57 Worthington Chauncey Ford, ed, 4 Journals of the Continental Congress 1774-1789 229-33 (Mar 23, 1776) (GPO 1906) (text of the resolution). Philadelphia merchants had petitioned Congress on the matter just before Congress acted. Morse, New England Privateering at 41 (cited in note 28 ). Other states had petitioned previously, Rhode Island most vociferously among them. Fowler, Rebels Under Sail at 47-49 (cited in note 29).

${ }^{29}$ Ford, ed, 4 Journals of the Continental Congress at 229-30 (cited in note 37).

Id at 230-31.

${ }^{40}$ Id at 231-32. Owners, captains, and crew contracted for the proportions, which the prize court would allocate.
} 
holders of letters of marque and reprisal that emphasized the project's commercial nature and judicial "supervision." Congress sent blank commissions to the states; the states then filled them out and gave them to the chosen applicants. ${ }^{41}$ Any party receiving a commission had to post a bond promising neither to depart from his commission "to make Captures of British Vessels and Cargoes" nor to transgress Congress's instructions. ${ }^{42}$ The instructions authorized commissioned ships to "by force of arms, attack, subdue, and take" all British ships.

But the force was to be directed at the capture of British ships, not their total destruction. Privateers were to bring ships and their cargoes to American ports for court proceedings and were to "keep and preserve every ship or vessel, and cargo . . . until they shall . . . be adjudged lawful prizes; not selling, spoiling, wasting, or diminishing the same, or breaking the bulk thereof, nor suffering any such thing to be done."43 Congress warned against any killing "in cold blood," maiming, or torturing, promised severe punishment, and warned that any act contrary to instructions might not only lead to forfeiting the bond but also to liability for damages. ${ }^{44}$

Congress modified the law throughout the war, but the modifications continued to reflect the commercial nature of letters of marque and reprisal..$^{45}$ A 1780 revision granted privateers

${ }^{11}$ For examples, see 11 Minutes of the Supreme Executive Council of Pennsylvania 23, 21 (Nov 13, 1776) (Fenn 1852) (granting commissions for "Letters of Mark," naming the captains and owners, and stating the size and armament of each ship). See also The Petition of Stephen Joseph Rouget (Aug 30, 1777), in Samuel Hazard, ed, 5 Pennsylvania Archives 569 (Severns 1853) (petition to the governor for a commission). For a flurry of letters between the Pennsylvania executive council, hungry for blank commissions, and the President of Congress, sending them as fast as he could, see Hazard, ed, 6 Pennsylvania Archives at 327-28, 378, 670, 726, 727 (cited in note 28), and Samuel Hazard, ed, 7 Pennsylvania Archives 224, 536 (Severns 1853).

" Ford, ed, 4 Continental Congress at 252-53 (Apr 3, 1776) (cited in note 37).

4 Id at 253-54.

"Id at 254.

4S Unlike many other laws of the notoriously feeble Continental Congress, most states followed these. Massachusetts and Rhode Island quickly revised their laws to conform to Congress's. Morse, New England Privateering at 52 (cited in note 28). Other states passed laws setting up prize courts and authorizing the executive to issue the commissions that Congress supplied. Although the states controlled the prize courts, Congress set up an appeals committee that evolved into a regular court. See, for example, Charles Hoadly, ed, 15 The Public Records of the Colony of Connecticut 280-81, 318-19 (Case, Lockwood 1890) (resolutions of May 1776, carrying out Congress's resolutions). The only real breach of Congress's rules was the states' inconsistency in sending the required congressional bonds, see Morse, New England Privateering at 53-54 (cited in note 28), and, later in the war, efforts to restrict appeals, id at 55-56. While states could require bonds in addition to congressional ones, and often did, they rarely issued their own commissions, even though the Articles of Confederation, which took effect in 1781, authorized them to do so "after a declaration of war by the United States." Articles of Confederation, Art 6, § 5, reprinted 
the new power to seize property "by land as well as by water" and admonished them not to seize neutral property or ships. ${ }^{46}$ Laws, enacted in 1781, aimed to be harsher on the British, to end any "indulgences and exemptions." Nevertheless, they merely granted private ships "general reprisals" to seize "ships, vessels, and goods, belonging to the King or Crown of Great Britain, or to his subjects," and required "all manner of captures, seizures, prizes and reprisals of all ships and goods" to pass through a prize court. ${ }^{47}$

\section{B. The Commercial Nature of Privateering in the Revolutionary War}

Privateering was far more of a business than a military exploit. ${ }^{48}$ This Section demonstrates this claim first by direct historical evidence, then by considering criticisms of revolutionary privateers, the privateers' aversion to and incompetence in true military action, and the largely commercial nature of even their excesses.

1. Privateering as business.

Above all, privateering was a business. ${ }^{49}$ While its military value-still much debated-was in "commerce-destroying" and in "harassing the Commerce of the Enemy," this was only one

in 1 Stat $4,5(1778)$.

${ }^{45}$ Worthington Chauncey Ford, ed, 16 Journals of the Continental Congress 1774. 1789 404-08 (May 2, 1780) (GPO 1910). Additional instructions later that year confirmed Congress's concern for not seizing neutral ships. Worthington Chauncey Ford, ed, 18 Journals of the Continental Congress 1774-1789 1097-98 (Nov 27, 1780) (GPO 1910).

${ }^{17}$ Worthington Chauncey Ford, ed, 19 Journals of the Continental Congress 17741789 314-16 (Mar 27, 1781), 360-64 (Apr 7, 1781) (GPO 1912). The exemption at issue was Bermuda, which had been friendly to America. The 1781 law largely ended the exemption, including only an exemption for a particular load of salt. Id at 316.

${ }^{4 y}$ Scholars have often overlooked this. See Morse, New England Privateering at 538 (cited in note 28) ("I]nsufficient emphasis has usually been laid upon the economic, as opposed to the military, aspects of privateering. . . Probably most people at the time usually thought of it in that light, as is suggested by the frequent references to the (privateering business.").

${ }^{49}$ See Paullin, Navy of the American Revolution at 149-51 (cited in note 29).

"The term "commerce-destroying" is ubiquitous in descriptions of privateering and letters of marque. One historian has proclaimed that "[t]he essential feature of privateering is commerce destroying." Maclay, History of Privateers at xxiii (cited in note 7). See also, for example, Fowler, Rebels Under Sail at 13 (cited in note 29) ("destroying enemy commerce"); Gardner W. Allen, 2 A Naval History of the American Revolution 662 (Houghton Mifflin 1913) ("commerce destroying"); Paullin, Navy of the American Revolution at 147 (cited in note 29) ("commerce-destroying").

${ }^{51}$ Allen, Massachusetts Privateers at 47 (cited in note 15), quoting a petition to Massachusetts authorities for a commission. This effect cut the other way, as British privateers upset American trade. Thomas Jefferson, as governor of Virginia, frequently com- 
side of the coin. Privateering was also commerce-producing, which was the only reason private parties would run the risks of fitting out their ships. What the privateers "destroyed," or rather seized, became the property of the crew and owners of the privateering vessel, who could sell their capture at great profit. This ersatz commerce was the "life blood of New England" during the Revolution, as the region quickly learned every time it embargoed privateers and letters of marque..$^{52} \mathrm{John}$ Adams lamented one such embargo by stating his opposition to "all shackles upon Trade." ${ }^{.53}$ Besides supplying essentials to both private citizens and the army (for the right price), privateers introduced a booming supply of previously rare goods from the West Indies. ${ }^{54}$ They also sustained an economy crippled by British blockades: over two thousand private American armed vessels roamed the seas during the Revolution, employing seventy thousand men, which does not include the employment that the privateers and letters of marque sustained ashore. ${ }^{55}$ Privateering thus was the business of "harassing the[ ] enemy and profiting by the operation. ${ }^{\$ 56}$

plained about this. See, for example, Thomas Jefferson to John Jay (June 19, 1779), in Julian P. Boyd, ed, 3 The Papers of Thomas Jefferson 4, 5 (Princeton 1951). See also Jefferson to the Committee of Congress at Headquarters (July 2, 1780), in Boyd, ed, 3 Papers of Thomas Jefferson at 476, and Jefferson to Samuel Huntington (July 2, 1780), in Boyd, ed, 3 Papers of Thomas Jefferson at 477. For a brief account of one raid in Chesapeake Bay, see James L. Howard, Seth Harding, Mariner: A Naval Picture of the Revolution 9192 (Yale 1930).

${ }_{52}$ Morse, New England Privateering at 397 ("life blood"), 200 (embargo) (cited in note 28). The embargoes aimed to shore up sagging naval and army recruitment.

${ }^{53}$ John Adams to James Warren (Apr 6, 1777), in Robert J. Taylor, ed, 5 Papers of John Adams 144, 145 (Belknap 1983).

${ }^{5}$ Allen, Massachusetts Privateers at 17 (cited in note 15), quoting James Warren to Samuel Adams (Aug 15, 1776). Paullin, Navy of the American Revolution at 150 (cited in note 29) ("Due credit must always be given to the hardy and venturesome privateersmen for supplying the army and navy with the sinews of war," although "it was to be had by paying a good round price for it in the open market."). John Adams was a zealot for privateering during the War. He claimed that New England, the center of privateering, was supplying the rest of the colonies at reduced prices and that the Continental Army would have been powerless without supplies from the privateers. John Adams to William Tudor (Mar 22, 1777), in Taylor, ed, 5 Papers of John Adams at 120-21 (cited in note 53).

${ }^{55}$ Allen, 1 Naval History at 47 (cited in note 28); Morse, New England Privateering at 397-98 (cited in note 28) (" " $\mathrm{PJ}$ rivateering had to a large degree taken the place of that commerce which was the life blood of New England. The privateers brought in the goods-acquired by capture instead of by purchase or exchange-and gave the employment provided in peace time by ordinary commerce. . . . [A]lmost all New England was concerned in [privateering], one way or another."); id at 538 ("The privateering of the Revolution, including the work of the letters of marque, provided a substitute for peacetime trade. ... Privateering gave employment, uncertain and dangerous though it was, to New England's maritime resources ... and such employment was indispensible . . . .").

${ }^{66}$ Allen, Massachusetts Privateers at 13 (cited in note 15). 
It is therefore no surprise that privateering and legitimate trade existed in inverse proportion during the American Revolution and were usually conducted by the same persons. ${ }^{57}$ As the British increased their harassment of American trade, merchants saw privateering as the natural alternative. Privateering was a "kindred occupation" by which these "[m]erchant-privateer owners" might recover the losses to their trading businesses. ${ }^{58}$ Even governments referred to these vessels' actions as "mercantile voyages. ${ }^{\prime 59}$ So privateering was both an alternative to trade and a form of trade itself. ${ }^{60}$

While the risks of privateering exceeded those of normal trading, the potential gains were also that much greater. Entire fortunes could be created: "Stories of men made wealthy for the rest of their lives by a single voyage filled seaport taverns from Boston to Lorient." ${ }^{\prime 1}$ The peak year for privateering was 1776, and it is no surprise that this year was popularly named not with reference to the military, but rather with reference to the year's monstrous profitability: "The Harvest." Many other privateers, seeking to match this success, found only sorrow in their search for riches. ${ }^{63}$ With good reason, historians have compared the

${ }^{67}$ Morse, New England Privateering at 395 (cited in note 28) (Entrance into the war by France in 1778 and Spain in 1779 on America's side led to rising American trade and a corresponding drop in privateering.); id at 533 (discussing refitting of the privateer Grand Turk for "merchant service" in 1783).

6 Howard, Seth Harding at 68 (cited in note 51) ("kindred occupation"); Morse, New England Privateering at 187, 191 (cited in note 28) ("merchant-privateer owners"). See also Paullin, Navy of the American Revolution at 149 (cited in note 29) (a "recompense" for lost commerce); John Dewar Faibisy, Privateering and Piracy: The Effects of New England Raiding Upon Nova Scotia During the American Revolution, 1775-1783 ii (unpublished $\mathrm{PhD}$ dissertation, $\mathrm{U}$ Mass 1972) (available via WorldCat) (Frustrated traders "turned to privateering and piracy" in order to "recoup their losses.").

${ }^{59}$ Resolutions of Congress (Nov 10, 1780), in Samuel Hazard, ed, 8 Pennsylvania Ar chives 603, 603-04 (Severns 1853); Proceedings of the General Assembly (Jan 17, 1781), in John Russell Bartlett, ed, 9 Records of the State of Rhode Island and Providence Plantations in New England 314, 322 (Alfred Anthony 1864).

\% Allen, Massachusetts Privateers at 13 (cited in note 15) ("the trade of privateering").

" Fowler, Rebels Under Sail at 282 (cited in note 29). See also Paullin, Navy of the American Revolution at 149-50 (cited in note 29) (recounting tale of someone drawing "a competence sufficient for almost a lifetime" from a privateering mission); Allen, Massachusetts Privateers at 53 (cited in note 15) ("The foundations of many fortunes . . . were laid by these enterprising mariners."). Famous beneficiaries of this practice include $\mathrm{Na}$ thaniel Shaw, see Morse, New England Privateering ch 13 (cited in note 28), and Louis F. Middlebrook, 2 History of Maritime Connecticut During the American Revolution: 1775 1783 50-53, 207-09 (Essex Inst 1925); Robert Morris, see Arthur D. Pierce, Smugglers' Woods: Jaunts and Journeys in Colonial and Revolutionary New Jersey 56-57 (Rutgers 1960); and the Cabot family of Beverly, Massachusetts, see Morse, New England Privateering ch 18 (cited in note 28 ).

62 Morse, New England Privateering at 117 ("The Harvest"), 134-37 (the profits), 492 (comparing 1782 to earlier years) (cited in note 28).

${ }^{*}$ Allen, Massachusetts Privateers at 55 (cited in note 15); Paullin, Navy of the Ameri- 
"new trade" of privateering to stock market speculation and to a lottery. ${ }^{64}$

2. Opposition to privateering.

Tales of wild profiteering by privateers were bound to dismay the more military-minded in the country, and their concerns further illustrate the commercial as opposed to military nature of privateering. The two main complaints both derived from its profitability: privateering's lures deprived the official armed forces of potential recruits, and privateering corrupted public morals.

While many early in the War argued that privateering would be a nursery of seamen for the navy, it quickly revealed itself as "the mortal enemy of the regular naval establishment" and a magnet for deserters from both the navy and army. ${ }^{65}$ Faced with a choice between the Continental Navy, in which the government received a sizable percentage of the prize, and privateering, in which the crew and owner divided it all and sailors received a higher base pay, the choice of "Mammon" and the seductive promise of glorious riches over patriotism and public service was easy. ${ }^{66}$ Even if the Continental Congress had not taken a cut of

can Revolution at 150 (cited in note 29).

${ }^{a}$ Allen, Massachusetts Privateers at 16 (cited in note 15) (speculation); Paullin, Navy of the American Revolution at 149 (cited in note 29) ("The new trade [of privateering] was as alluring as a lottery.").

${ }^{65}$ Morse, New England Privateering at 172 (cited in note 28). For an example of early enthusiasm for privateering as a means of building a navy, see The Committee of Secret Correspondence [Benjamin Franklin and Robert Morris] to Silas Deane (Oct 1, 1776), in William B. Willcox, ed, 22 The Papers of Benjamin Franklin 639, 644 (Yale 1982) ("The success in privateering and encouragement given by the Merchants will inevitably bring Seamen amongst us ... [and] encourage the breeding of seamen ....").

${ }^{e s}$ Paullin, Navy of the American Revolution at 149 (cited in note 29) (discussing "Yankee privateersmen, whose love for Mammon exceeded that for their country"). Many who criticize privateering grudgingly acknowledge that even if commerce-raiding could never win a war, the profit motive induced many to seek out-and to sell in the coloniescritical supplies for America's military, commerce, and other activities which depended on that commerce. See, for example, Morse, New England Privateering at 537-38, 397-98 (cited in note 28) (summarizing views of historians and emphasizing importance of privateering for providing supplies, commerce, and employment). These supplies were crucial in the latter half of the war, according to one historian, Maclay, History of Privateers at 206 (cited in note 7), and in the beginning, according to another, Allen, 2 Naval History at 663 (cited in note 50). Privateering also served a commerce-destroying functionunsettling the British fleet and impressing the French, see Morse, New England Privateering at 253-63 (British fears), 264-75 (French) (cited in note 28)-though the British disrupted American commerce as well. See, for example, The Commissioners [B. Franklin, A. Lee, and J. Adams] to Vergennes (Apr 19, 1778), in Robert J. Taylor, ed, 6 Papers of John Adams 42 (Belknap 1983) ("$[\mathrm{M}]$ any Adventurers to America are discouraged by the high Price of Insurance, and the Number of Captures made by the English, which together have an Operation almost equal to an Embargo."). 
the prize-two-thirds for much of the war-naval recruiters faced the additional difficulty that the Continental Navy could not devote all of its time to profit and plunder as could the privateers. ${ }^{67}$ Other less lucrative tasks interfered, such as hunting down British men-of-war, running dispatches, and guarding convoys and harbors. ${ }^{68}$ To the extent that the navy did raid foreign commerce, it did so partly to compete with privateers for recruits. ${ }^{69}$ States frequently grew frustrated with this lost manpower and embargoed privateers and letters of marque, or required them to prove that their crews contained no deserters. ${ }^{70}$ Pennsylvania tried offering rewards for information on anyone who deserted the army for privateering. ${ }^{71}$ Most of these efforts failed miserably. ${ }^{72}$

The second complaint against the private armed merchants-that they undermined public morals-also derived from the allure of profit rather than the ravages of war. Popular sentiment oscillated with the popular condition. Before the war, there was general opposition to privateering on moral and humanitarian grounds. The flush of battle and profit in 1776 quickly converted the opposition, as the country became "privateering mad." ${ }^{\text {73 }}$ Less than a year later, the masses had reverted, deciding that privateering endangered the war effort,

${ }^{67}$ Fowler, Rebels Under Sail at 281-84 (cited in note 29). See also Allen, Massachusetts Privateers at 14 (cited in note 15).

${ }^{69}$ Howard, Seth Harding at 69 (cited in note 51).

93 Paullin, Navy of the American Revolution at 348 (cited in note 29). Other reasons included military weakness and "the commercial spirit of the times." Id. See also Fowler, Rebels Under Sail at 69 (cited in note 29) ("IM]any people looked upon the navy as nothing more than a glorified privateering fleet.").

"See, for example, Proceedings of the General Assembly (July 1780), in Bartlett, ed, 9 Records of Rhode Island at 120, 144 (cited in note 59) (ending an embargo, except for privateers, so long as ships' masters or owners showed that their sailors' towns had met "the full quotas of men" and made an oath that none of their crew came from a town that had not met its quota; subjecting letters of marque to the same restriction but also forbidding them from carrying more than twelve men); Act of General Assembly (May 1780), in Charles J. Hoadly, ed, 3 The Public Records of the State of Connecticut 1, 13 (Case, Lockwood 1922) (embargoing "all privateers, letters of marque and armed vessels" until August, ... "except such as are in continental service ...."); Allen, Massachusetts Privateers at 14-15 (cited in note 15) (noting the repeated embargoes to fill army quotas and man the Continental Navy); Taylor, ed, 5 Papers of John Adams at 145 n 3 (cited in note 53) (summarizing Massachusetts embargoes in 1776 and 1777).

${ }^{21}$ Colonel L. Nicola to President Reed (May 23, 1780), in Hazard, ed, 8 Pennsylvania Archives at 262 (cited in note 59).

${ }^{22}$ John Adams, as usual, mocked the embargoes. Referring to a Massachusetts embargo, he wrote, "I doubt much whether you have got an hundred soldiers the more for your Embargo and perhaps you have missed Opportunities of taking many Prizes and several Hundreds of seamen." John Adams to James Warren (Apr 6, 1777), in Taylor, ed, 5 Papers of John Adams at 144, 145 (cited in note 53).

${ }^{23}$ Morse, New England Privateering at 117-18 (cited in note 28). 
since the thirst for profit allegedly divided loyalties. Privateermerchants bore the blame for any scarcity of goods and for high prices because it was thought that their greed had corrupted their patriotism. Privateering was "an all-pervasive evil, infecting the entire social fabric and undermining the morals and patriotism of New England." ${ }^{\text {"4 }}$ But embargoes made goods even more scarce and more expensive, and suddenly popular support for privateering rose again. ${ }^{75}$

\section{Reluctant and incompetent warriors.}

Privateersmen were traders, not fighters. Their aversion to battle, especially the owners', was easy to foresee. Clashing unnecessarily with a British warship was both folly and bad business, since such ships rarely carried the goods privateers sought. ${ }^{76}$ Flight was far preferable to fight. ${ }^{77}$ Fights with British privateers were more common and made more business sense, but the goal was still to capture (or recapture) the prize and to fight only as a last resort. ${ }^{78} \mathrm{~A}$ privateer might also spar with its

"Id Id 184. See, for example, William Tudor to John Adams (Sept 23, 1776), in Taylor, ed, 5 Papers of John Adams 36, 37 (cited in note 53) ("New England has Men of Sense and Honour who might soon become good Officers, but the Gentlemen there are so totally absorb'd by the Auri sacra fames [the Accursed thirst for goldl, and the Views of making Fortunes by Privateering, that no other consideration seems to be attended to.") (translation at Taylor, ed, 5 Papers of John Adams at $38 \mathrm{n}$ 4); William Tudor to John Adams (Oct 3, 1776), in Taylor, ed, 5 Papers of John Adams at 43, 44-45 ("I most heartily wish ... that young Gentlemen in Boston and everywhere else would prefer engaging in the best of all Causes, that of defending their Country, to raising dishonorable Fortunes by privateering."). A frequently quoted complaint is that of William Whipple to Josiah Bartlett (July 12, 1778), in Allen, 1 Naval History at 48 (cited in note 28):

No kind of Business can so effectually introduce Luxury, Extravagance and every kind of Dissipation, that tend to the destruction of the morals of people. Those who are actually engaged in it soon lose every Idea of right \& wrong, \& for want of an opportunity of gratifying their insatiable avarice with the property of the Enemies of their Country, will without the least compunction seize that of her Friends.

${ }^{75}$ Morse, New England Privateering at 200 (cited in note 28).

${ }^{76}$ Maclay, History of Privateers at 23 (cited in note 7). See also J. Roger Fredland, et al, American Sea Power Since 177570 (Lippincott 1947) (telling of an American privateer captain in the War of 1812 who boarded and captured a British naval schooner, then apologized to his employers for "having sought a contest with a king's ship, knowing that is not our object").

${ }^{\pi}$ Fowler, Rebels Under Sail at 13 (cited in note 29) ("[The privateers'] task was to take merchantmen while eluding the enemy's warships.").

${ }^{78}$ See, for example, Maclay, History of Privateers at 138, 142-45 (cited in note 7) (recounting the celebrated duel of the American privateer General Pickering (owned by Nathaniel Shaw) and the British letter of marque Achilles off the coast of Bilboa, Spain, on June 4, 1780. The battle occurred only because the Achilles captured a prize the General Pickering had taken. The Achilles fled after a three-hour battle, and the General Pickering recaptured its prize.). For another account, see Morse, New England Privateering at 441-51 (cited in note 28), which makes clear that the Achilles's meddling with the 
prey, the goal being even more clearly to profit, but one hoped the fighting did not cause the prey to sink, at least not until it had been separated from its cargo. ${ }^{79}$ For privateers and letters of marque, fighting was accidental. ${ }^{80}$ Owners wanted their ships in one piece, and crews dreamed of easy pickings-seeking their glory in wealth, not heroics. ${ }^{81}$ The thoughts of a typical commander of a privateer or letter of marque were easy to read: preserve the ship and avoid risks. ${ }^{82}$ Such a mentality was hardly that of a warrior, but it conformed to the accepted commercial nature and role of privateering in the Revolution. As John Adams wrote in praise of privateering, "[I]t is by cutting off supplies, not by attacks, sieges, or assaults, that I expect deliverance from enemies." 83

Given such a nonmilitary mentality, nearly every privateer effort at coordinated combat, whether with other privateers or American naval ships, predictably failed. ${ }^{84}$ Privateers tended to roam individually and so lacked organizational skills or any inclination to follow orders from other ships. ${ }^{85}$ Hoping that the crews would overcome this deficiency was an exercise in selfdelusion, since many joined privateers precisely for the lax disci-

General Pickering's prize sparked the battle.

"See Middlebrook, 2 Maritime Connecticut at 207-08 (cited in note 61) (noting the battle of the American privateer Revenge and the British ships the Thames and the Sarah, which the Revenge won, with the result that the Revenge's commander manned the Thames and sent it to Boston to be sold for prize); Maclay, History of Privateers at 23 (cited in note 7) (an overwrought observation of how much sinking one's prize while attempting to capture it was frowned upon).

ST See Pierce, Smugglers' Woods at 62 (cited in note 61) ("[M]any a privateer could haul in prize after prize without fight or bloodshed ....").

${ }^{*}$ See Fowler, Rebels Under Sail at 282 (cited in note 29) (Recruits were "entranced by glorious stories of richly laden Indiamen sailing unescorted and ready to strike their flag at the mere sight of an open gun port."); James Sullivan to John Adams and Elbridge Gerry (Oct 11, 1776), in Taylor, ed, 5 Papers of John Adams 50, 52 (cited in note 53) ( $[\mathrm{M}]$ en go on Board privateers where they are in Little danger from fighting and get more of the prizes they take.").

$\$_{2}$ Fowler, Rebels Under Sail at 116 (cited in note 29).

${ }^{2}$ Allen, 1 Naval History at 50 (cited in note 28), quoting a September 16, 1780, letter from John Adams to the President of Congress.

: Allen, 2 Naval History at 663 (cited in note 50); Allen, Massachusetts Privateers at 50 (cited in note 15) ("Privateers were ill adapted for cruising in squadrons and failed in nearly all attempts at cooperation with regular ships or with each other. . . [W] [hen anything like manouvring was required, they were incapable of concerted action."); Maclay, History of Privateers at xxiv (cited in note 7) ("There are a few instances where our early privateers rendered assistance to the regular navy; but then there are more instances where they were a positive hindrance.").

Maclay, History of Privateers at xxiv (cited in note 7) (lack of organizational skills); Fowler, Rebels Under Sail at 95, 113-14 (cited in note 29) (lack of organization and refusal to follow orders). 
pline on board. ${ }^{86}$ The various committees and boards that struggled to administer the navy quickly learned that joint operations with privateers were worth avoiding. ${ }^{87}$

An example of the privateers' ineptitude for battle is the Penobscot Expedition in 1779 against a British base on the Penobscot River in Maine. It was the largest fleet assembled during the war-and the largest American amphibious operation until the Mexican War over sixty years later. ${ }^{88}$ Massachusetts organized and funded a fleet that totaled about forty ships, of which at least twenty were armed. Twelve to sixteen of the ships were privateers (impressed and insured against loss by Massachusetts). ${ }^{89}$ Nearly every ship was lost, at extraordinary cost to Massachusetts, and while American bungling was ubiquitous, privateers clearly contributed to the failure. General Solomon Lovell, commanding land operations, repeatedly sought to attack, fearing the arrival of British reinforcements. Commodore Dudley Saltonstall, commanding the fleet, stalled, and Lovell could not attack without naval support. Historians pin much of the blame for the Commodore's timidity on the privateers, who, more concerned with protecting their ships than with military tactics, urged him to stall. When the British reinforcements did arrive-just as Saltonstall got around to acting-the privateers "fled like stampeded cattle. ${ }^{900}$ Such behavior cemented the Continental government's aversion to joint actions with privateers. ${ }^{91}$

${ }^{86}$ See John W. Jackson, The Pennsylvania Navy 1775-1781: The Defense of the Delaware 13 (Rutgers 1974) ("R]egular naval service, with its discipline and restraints, did not offer the allure that the almost total freedom of a privateersman could guarantee."); Allen, 1 Naval History at 50 (cited in note 28) (same).

${ }^{87}$ Paullin, Navy of the American Revolution at 153 (cited in note 29); Allen, 2 Naval History at 498 (cited in note 50); Fowler, Rebels Under Sail at 114, 119 (cited in note 29). Thus Lobel is at best imprecise and at worst completely wrong when he claims privateers fought "in place of or alongside public naval vessels." Lobel, 134 U Pa L Rev at 1044 (cited in note 3). Those interested in the shifting "organization" of naval governance during the Revolution should look to the chart in Fowler, Rebels Under Sail at 62.

ॠ Fowler, Rebels Under Sail at 114 (cited in note 29).

${ }^{8}$ On the numbers, compare the accounts of Allen, 2 Naval History at 420-21 (cited in note 50); Fowler, Rebels Under Sail at 113-14 (cited in note 29); and Paullin, Navy of the American Revolution at 349-50 (cited in note 29).

${ }^{\infty}$ Allen, Massachusetts Privateers at 52 (cited in note 15).

${ }^{91}$ It also led to a court-martial and discharge for Saltonstall. For full accounts of the Expedition, see Morse, New England Privateering at 343-81 (cited in note 28); Allen, 2 Naval History at 419-38 (cited in note 50); Fowler, Rebels Under Sail at 111-18 (cited in note 29); and Paullin, Navy of the American Revolution at 347-53 (cited in note 29). On the Continental government's policy, see Fowler, Rebels Under Sail at 114, 119 ("The Maritime Committee always looked askance at such joint ventures, and the events at Penobscot fully justified their misgivings. . . But for practical reasons of manning and supply they were often forced to relent in this policy and allow exceptions.").

A few other examples further illustrate the privateers' skittishness in true warfare. Two years before the Penobscot Expedition, nine privateers sailed from Boston with two 
4. Privateer misbehavior: the rule and some exceptions.

Notwithstanding the bad reputation that privateers acquired for breaching their instructions and for unauthorized pillaging, they generally behaved themselves. ${ }^{92}$ This is exactly what one would expect of people who were more traders and businessmen than warriors. The excesses prove the rule: privateering in Long Island Sound shows that actions beyond merely seizing ships and their cargoes were rare and generally discouraged by authorities and that "pillaging," even when unauthorized, usually was confined to seizing property. ${ }^{93}$

Privateering in Long Island Sound in the latter half of the war was fierce, but it was the exception in the Revolution. The fighting erupted between Connecticut and loyalist Long Island and Connecticut history is filled with governmental efforts to hold the privateers within their proper bounds. ${ }^{94}$ While Connecticut did issue special commissions for cruising in Long Island Sound, ${ }^{95}$ it soon had second thoughts. In January 1781, it issued

Continental frigates for a month-long cruise. Within a few days of leaving port, all but one of the privateers had scattered, and if they made any efforts to rejoin the "fleet," they were unsuccessful. See Morse, New England Privateering at 215-17 (cited in note 28). In 1781, almost all of the Cabots' privateers appeared off the Irish coast, most likely part of a plan by the Cabots to have their ships cruise the British Isles as a fleet. They came no closer to creating such a fleet than a wispy four-ship squadron that evaporated at the first sight of a British man-of-war, offering "merely [ ] another example of the inability of privateers, no matter how strong or numerous, to cope with regular naval vessels." Id at 48 . In 1782, five American privateers joined forces to raid the British island of Tortola in the West Indies, but navigational errors and poor planning undermined the effort. Their threat to bombard the port town crumbled as soon as one of the privateers found itself threatened. See id at 502-06. Maclay gives a more favorable account, but it is clouded by his enthusiasm; he also admits to lacking information. Maclay, History of Privateers at 214-15 (cited in note 7).

${ }^{92}$ Allen, Massachusetts Privateers at 15 (cited in note 15) ("American privateersmen in general conducted themselves in an orderly manner. ... [ [] $f$ excesses were committed they must have been rare. The commonly expressed opinion that privateering was little better than piracy did not apply to these men."). British "pillaging" in Chesapeake Bay and along the Virginia coast, much bemoaned by Thomas Jefferson, see note 51, appears to have confined itself to the usual seizure of ships, often from their ports. See Howard, Seth Harding at 91-92 (cited in note 51); Thomas Jefferson to the Committee of Congress at Headquarters (July 2, 1780), in Boyd, ed, 3 Papers of Thomas Jefferson at 476 (cited in note 51); Jefferson to Samuel Huntington (July 2, 1780), in Boyd, ed, 3 Papers of Thomas Jefferson at 477 (both letters lamenting the swarm of British privateers, but only because they were cruising in the Bay waiting to pick off any shipping).

${ }^{\varsigma}$ For a discussion of the additional problem of seizing neutral or friendly property, see text accompanying notes 127-32. See also Allen, Massachusetts Privateers at 16 (cited in note 15) ("This reprehensible practice was afterwards corrected by stringent regulations.").

Morse, New England Privateering at 83-84, 222, 385-86 (cited in note 28). It flared in 1779 , when the British left Newport, Rhode Island. Id at 383.

5 Id at 556. See, for example, Hoadly, ed, 3 Records of Connecticut at 103, 103 (May 29,1780 ) (cited in note 70) (governor and council of safety issuing a commission "to cruize 
a blanket repeal of all commissions, on account "of the many evils committed by the armed boats in this State." That fall, state authorities acted more precisely, by revoking the special permission to seize property from land on Long Island.$^{97}$ This permission had been an exception to the usual rules of privateering, ${ }^{98}$ and both of these resolutions demonstrate by their wording that the proper role of privateers was to seize enemy property and to do so at sea. ${ }^{99}$

\section{No Governmental Funding of Privateers and Letters of Marque}

The commercial nature of privateering made possible a closely related but key aspect little noted in the current literature: the privateers relied entirely on private funding. While they depended on the government for their authorization and legal title to their prize and nominally had governmental instructions to obey, they enjoyed no access to the government's purse. ${ }^{100}$ Thus the standard commission authorized privateers "to fit out" a ship. ${ }^{101}$ Their prizes supported them.

in the Sound"), and id at 118, 119 (June 30, 1780) (same).

${ }^{96}$ Hoadly, ed, 3 Records of Connecticut at 292, 292-93 (Jan 23, 1781) (cited in note 70).

${ }^{n}$ Id at 512, 513 (Sept 15, 1781).

${ }^{\$}$ Morse, New England Privateering at 386 (cited in note 28).

${ }^{99}$ Hoadly, ed, 3 Records of Connecticut at 292, 292 (Jan 23, 1781) (cited in note 70) (denouncing privateers who received commissions "for the pretended purpose of making captures on the enemy and preventing and intercepting illicit trade and traders" but then used them to commit "evils"); id at 512, 513 (Sept 15, 1781) (noting that commissions for cruising the Sound had empowered armed boats "not only to cruise on the high seas against the enemy but to land on Long Island and there take all British property").

The lessons of privateering against Nova Scotia are similar. While every major coastal town other than Halifax (the British base in North America) endured some American raiding, many of the raiding ships lacked commissions. They were thus pirates and criminals rather than privateers; true privateers focused on their usual business of seizing ships. Even the worst pillaging tended to be confined to property seizure. Massachusetts denounced robberies along the Nova Scotia shore and ordered special bonds to prevent them. In 1780, Congress did authorize seizure on land, see text accompanying note 46 , but on the whole "piracy predominated over privateering" in Nova Scotia-the land seizures were not the work of commissioned privateers. Faibisy, Privateering and Piracy at 102 (cited in note 58). The "grievances" that Nova Scotians endured tended to be "economic" and most of these involved seizures of their ships in harbor. Id at 100. For an account of one famous raid that pushed the limits of the idea of privateering as prizetaking, see Allen, 2 Naval History at 595-96 (cited in note 50) (recounting the raid on Lunenberg).

${ }^{100}$ The exception was when the government impressed privateers for naval missions, in which case it usually insured the owners against loss. Examples include the Penobscot Expedition and the voyage of the Hancock and Boston, see notes 88-91 and accompanying text.

${ }^{101}$ Ford, ed, 4 Journals of the Continental Congress at 229, 230 (cited in note 37). Massachusetts's law was more explicit on this. See Mass Armed Vessels Act, 1775 Mass Acts ch $7 \S 2$, reprinted in 5 Mass Acts and Resolves at 437 (cited in note 31) ("[T]he council ... 
Privateering was an investment opportunity. While Nathaniel Shaw and those with similar wealth often could finance their own ships, consortiums for this purpose were numerous, both for raising capital and for spreading risk. ${ }^{102}$ Records are replete with accounts of "part owners" of ships and with the petitions of joint investors or owners of shares. ${ }^{103} \mathrm{~A}$ single individual could have shares in numerous ships, ${ }^{104}$ and ownership of a single ship was often subdivided minutely, ${ }^{105}$ even into "parts of shares." 106

Privateer owners paid for everything. Besides the ship itself, ${ }^{107}$ this included gunpowder and cannons, often bought from the state (since they were rationed), and the payroll, composed of both wages and a division of any prize. ${ }^{108}$ Payment by private

shall be [ ] impowered to commission, with letters of marque and reprisal, any person or persons within this colony, who shall, at his or their own expence, fix out and equip ... any vessel.") (emphasis added). Nathaniel Shaw once requested a commission by explaining that he had "put on board" his ships "eight carriage guns and men sufficient to fight them." Middlebrook, 2 Maritime Connecticut at 50 (cited in note 61).

${ }_{102} \mathrm{John}$ A. McManemin, Sea Raiders from Connecticut During the American Revolution, Part One (Connecticut) (Introduction) (Ho-Ho-Kus 1995). Id, Part Two (Pennsylvania) at 292-93.

${ }^{103}$ See, for example, Bartlett, ed, 8 Records of Rhode Island at 234 (May 19, 1777) (cited in note 59) (noting that Samuel Sheffield sought and received a commission for himself and "such others as may join him" in fitting out a privateer); Hoadly, ed, 15 Records of Connecticut at 462 (July 3, 1776) (cited in note 45) (granting a letter of marque to "Capt. Thorp . . . part owner of the privateer Broome"); id at 525 (Sept 26, 1776) (mentioning ownership of a privateer by "Messrs. Lyon \& Co."); Allen, Massachusetts Privateers at 46-47 (cited in note 15) (quoting the petition of Joseph Cutler and noting that he sought and received a commission for "himself and others concerned in the armed privateer Brigantine called the Gates").

${ }^{14}$ See John Bondfield to Commissioners (Aug 26, 1778), in Taylor, ed, 6 Papers of John Adams at 397, 398 n 1 (cited in note 66) (noting a privateer captain "who either commanded or held some interest in at least ten different vessels during the . . . Revolution"). See also note 61 (Nathaniel Shaw).

${ }^{15}$ Robert Morris claimed a $1 / 24$ share in the infamous privateer Phoenix. Worthington Chauncey Ford, ed, 14 Journals of the Continental Congress 1774-1789 838 (July 16, 1779) (GPO 1909).

${ }^{1 \kappa}$ Colonel L. Nicola to President Reed (May 23, 1780), in Hazard, ed, 8 Pennsylvania Archives at 262, 262 (cited in note 59).

${ }^{107}$ See, for example, Jackson, Pennsylvania Navy at 286 (cited in note 86).

${ }^{16}$ See, for example, Hoadly, ed, 15 Records of Connecticut at 401,460 (cited in note 45) (state selling gunpowder to a privateer); id at 525 (state selling cannons to a privateer); id at 459 (setting price for gunpowder). Benjamin Franklin, while serving in Congress, noted the distinction between "Vessels and Cargoes taken by the armed Vessels in the Pay of the Continent and those taken by Individuals." Willcox, ed, 22 Papers of Benjamin Franklin at 230, 234 (Oct 21, 1775) (cited in note 65). The crew put aboard one of Nathaniel Shaw's prizes signed the following statement:

We the Subscribers (Seamen on board the Sloop American Revenue) do acknowledge to have Received of Nathaniel Shaw Junr the sum of One hundred Dollars each of us which is in full of our prize Money \& in full of our Wages on board the Guinea Ship called the Mary ... \& taken by sd Sloop . . \& \& in full of all Demands on any prize from sd Sloop this present Cruse. 
parties rather than the government was one of the allures of privateering, since it was more certain and more lucrative. State officials frowned on anyone remaining on the navy payroll while also profiting from privateering and kept clear the distinction between government ships and private ones. ${ }^{109}$ Owners also faced the not insignificant cost of the bond. ${ }^{110}$ One set of privateer owners, seeking an exemption from an embargo, pleaded that they had "been at great panes and Expence in fitting sd. ship." Failed or fatal privateer missions did not receive any compensation from Congress, such as the pension naval sailors received. ${ }^{112}$ Owners even had to pay the costs of caring for any prisoners (sailors removed from prize ships) and delivering them to congressional agents or to a jail. ${ }^{113}$ States were also not above borrowing money from merchants to finance government ships. ${ }^{114}$

\section{Governmental Supervision of Privateers: The Prize Courts}

Given their financial independence, it is no surprise that privateers and letters of marque of the American Revolution largely avoided governmental supervision. However, they often faced real checks, but from the judiciary rather than from executive or legislative authorities. Focusing on the legitimacy of and title to prizes, the prize courts served a dual function: they provided a governmental check on the privateers, but also secured the privateers' income and financial independence.

The life of a privateer or letter of marque was one of "almost total freedom..115 The regulations ${ }^{116}$ had little bite: commissions were granted as a matter of course, usually immediately, although the bond might take a bit longer. ${ }^{117}$ Almost as easy to get

Quoted in McManemin, Sea Raiders Part One (Connecticut) at 23 (cited in note 102).

${ }^{100}$ See Jackson, Pennsylvania Navy at 300-01 (payroll overlap), 319 ("Council never made the mistake of considering [merchant-owned ships] elements of the State navy.") (cited in note 86).

${ }^{110}$ McManemin, Sea Raiders Part One (Pennsylvania) at 292 (cited in note 102) (noting that bonds tended to go for $\$ 20,000$ ). On bonds generally, see text accompanying notes 34 and 42 , and note 45.

${ }^{111}$ Quoted in Allen, Massachusetts Privateers at 46 (cited in note 15).

${ }^{112}$ Maclay, History of Privateers at 22-23 (cited in note 7).

${ }^{113}$ Ford, ed, 16 Continental Congress at 408 (May 2, 1780) (cited in note 46); Ford, ed, 19 Continental Congress at 363 (Apr 7, 1781) (cited in note 47). It appears that states sometimes reimbursed some of these expenses or at least had power to do so. See George Mason to Thomas Jefferson (July 16, 1779), in Boyd, ed, 3 Papers of Thomas Jefferson at 37,37 (cited in note 51) (suggesting Virginia pay a privateer's expenses in maintaining prisoners on board since arriving in port).

${ }^{114}$ Jackson, Pennsylvania Navy at 307-08 (cited in note 86).

${ }^{115} \mathrm{Id}$ at 13.

${ }^{116}$ See Part II.A.

${ }^{117}$ Allen, Massachusetts Privateers at 44 (cited in note 15). 
were exemptions from the repeated embargoes. ${ }^{118}$ Privateer captains, once at sea, "were not bothered with any orders more limiting than the roving commission," 119 which was broad indeed. A typical one limited the privateer's range to nine degrees west longitude on the east, twelve degrees north latitude on the south, and "the Shoals of Nantucket" on the west, which amounts to most of the North Atlantic. ${ }^{120} \mathrm{~A}$ slightly less confining example is a successful petition for a commission "to cruise against the Enemies of these united States."121

Nevertheless, the prize courts, including the appeals court in Congress, were a real check on privateers, often the only one. ${ }^{122}$ They were also critical to the privateers: captors had no title to captured property until a court granted it. ${ }^{123}$ The courts' job was to "libel" prizes, which meant determining what counted as "lawful prize" and whether the prize (in whole or in part) at issue met those requirements. ${ }^{124}$ Even with the fires of American patriotism and disdain for the British burning brightly, these courts appear to have taken their role seriously and adjudicated fairly. ${ }^{125}$ For example, the treaty that ended the Revolutionary

\footnotetext{
${ }^{118}$ Id at $45-47$.

${ }^{119}$ Howard, Seth Harding at 69 (cited in note 51).

${ }^{123}$ Paullin, Navy of the American Revolution at 328 (cited in note 29).

${ }^{122}$ Allen, Massachusetts Privateers at 44-45 (cited in note 15), quoting an April 13, 1778 petition of Daniel Martin.

${ }^{12}$ For the details on the Massachusetts courts, which were the first created and by far the most active during the war, see Allen, Massachusetts Privateers at 33 (cited in note 15). Massachusetts courts tried about 1,200 prizes during the war. Id at 53. For examples illustrating the importance of prize courts, see id at 53-55 (reprinting trial transcript on the Boston's capture of the Independence); Jackson, Pennsylvania Navy at 301-03 (cited in note 86) (case of the Active).

${ }^{123}$ Privateers could often avoid the tedium of prize courts. "When no one was looking, parts of cargoes could more readily be appropriated for private use" without awaiting adjudication. Paullin, Navy of the American Revolution at 147 (cited in note 29). The usual way to do this was to seize the cargo while setting the prize ship free. See Faibisy, Privateering and Piracy at 115 (cited in note 58).

${ }^{124}$ Ford, ed, 4 Continental Congress at 231 (cited in note 37) (Mar 23, 1776 resolution establishing court); Morse, New England Privateering at 71 (cited in note 28) (noting that this "law" was often "feeble" in practice); Miller $v$ The Ship Resolution, 2 US (2 Dallas) 1, 1-3 (Fed Ct App 1781) (noting that its rulings were guided by laws of Congress "and, where they are silent, by the laws, usage and practice of nations"; stating the issue of the case as "whether ... the ship or cargo, or both, or any part of the cargo, be a prize ..."; and explaining that "[p]rize is generally used as a technical term to express a legal capture ....").

${ }^{125}$ Morse, New England Privateering at 72 (cited in note 28) (The courts "probably discharged their functions with honesty and fairness."). One Massachusetts judge wrote John Adams with the details of a case in which the judges refused to condemn the prize (that is, refused to grant it to the captors). Apparently feeling some political pressure, he commented that "I trouble you with this that the Congress or Pensilvanians [sic] may not Suppose that Massachusetts is unwilling to Condemn prizes but I should wish the world to know that we will not pervert Justice on any account." James Sullivan to John Adams
} 
War set a deadline after which no prize could be taken. Some was, and courts ordered it all restored. ${ }^{126}$

The perennial difficulty was protecting the property and shipping of neutrals. ${ }^{127}$ Early ambiguities in the definition of lawful prize caused many embarrassments, such as captures of French and Swedish ships (both neutral countries at the time) and the return of two British prizes upon heated British protest against the use of French ports by American privateers at a time when France's treaties with Britain prohibited such action. ${ }^{128}$ In addition to these "just complaints" of foreign nations, ${ }^{129}$ the privateers were also unhappy, disliking the courts' evidentiary rules. ${ }^{130}$ Congressional resolutions in 1778,1780 , and 1781 all tried to prevent these indelicacies. ${ }^{131}$ Violation of the rules of neutrality could make one liable for damages plus interest, and if the violation were intentional and one were captured by the foreign nation, he would receive no assistance from the United States, but would suffer his fate alone. ${ }^{132}$

Since prize cases determined title, often to huge sums of money, the parties placed enormous importance on them. Political connections, therefore, did not lack attention. For example, Samuel Purviance was part owner of a privateer, whose captain had sent "a Valuable Prize" to a port in New Hampshire but had failed to put aboard it a copy of the privateer's commission and other necessary papers. Anticipating "some difficulties" in con-

(Sept 22, 1776), in Taylor, ed, 5 Papers of John Adams 34, 35 (cited in note 53).

${ }^{126}$ Morse, New England Privateering at 528-29 (cited in note 28). For an example, see the Salem Gazette's account (Apr 3, 1783) of the Brigantine Lively, quoted in Allen, Massachusetts Privateers at 210 (cited in note 15).

${ }^{122}$ See Miller, 2 US at 2 ("The rights of war can only take place among enemies, and therefore, a capture can give no right, unless the property captured be the property of an enemy."). A related problem was wrongful seizure of American ships. See McManemin, Sea Raiders Part One (Connecticut) at 24-25 (cited in note 102) (recounting the capture of the Sally by the American Revenue).

${ }^{123}$ See The Foreign Affairs Committee [Richard Henry Lee and James Lovell] to the Commissioners (May 14, 1778), in Taylor, ed, 6 Papers of John Adams 116, 118 (cited in note 66) (hoping that the treaty with France and recent proclamations on the rights of neutrals would leave "the minds of the Seamen relieved thereby from that unexplainable Mystery respecting their real prizes which before embarrassed them, that such irregularities will be less frequent or totally cease"); id at 120 n 5 (noting some of the embarrassments and Congress's efforts to prevent their repetition). The intrepid Captain Gustavus Conyngham was responsible for all four of the incidents mentioned in the text. Id at 120 n 5.

${ }^{120}$ Allen, Massachusetts Privateers at 35 (cited in note 15).

${ }^{130}$ Morse, New England Privateering at 403 (cited in note 28).

${ }^{131}$ Proclamation of May 9, 1778, reprinted in Allen, Massachusetts Privateers at 36-37 (cited in note 15); Ford, ed, 16 Continental Congress at 403-09 (May 2, 1780) (cited in note 46); Ford, ed, 19 Continental Congress at 360-64 (Apr 7, 1781) (cited in note 47).

${ }^{152}$ Proclamation of May 9, 1778, reprinted in Allen, Massachusetts Privateers at 36-37 (cited in note 15). 
demning the prize as a result, Purviance beseeched John Adams, then a member of Congress. He had never met Adams, but his brother had. Purviance hoped Adams might drop "a Line to some of your Freinds [sic] at Boston" to help work things out. ${ }^{133}$

\section{ThE CURRENT MisUSE OF THE MARQUE AND REPRISAL CLAUSE}

The scholars who allege an analogy between letters of marque and reprisal and modern forms of undeclared war overlook both the true historical nature of the letters and the most likely purpose of the Clause. The Clause makes most sense when one views it as granting Congress power over the form of war that it could not control through its power of the purse. In this purpose lies any modern relevance of the Clause, yet all examples that modern scholars offer involve federal funding. This Part first explains their errors of history and interpretation and then proposes a more credible understanding of the Clause.

\section{A. Two Errors of Recent Marque and Reprisal Clause Scholarship}

The scholars' first mistake is to assume that since people of the eighteenth century used terms interchangeably, they also used them to encompass numerous activities. The history belies such an assumption. Although terms such as "letter of marque," "letter of marque and reprisal," and "private armed vessel" were used "loosely" during the Revolution, ${ }^{134}$ one must understand "Ioosely" precisely. It means that people of that time used several similar terms to refer to a commonly understood type of activity: governmentally sanctioned seizure of foreign property by private parties who received no government funding. It does not mean that the terms were nebulous, enveloping every sort of undeclared war. Lobel displays this error when he treats letters of marque as authorizing shipowners "to go out and fight the enemy," to fight "in place of or alongside public naval vessels," and to engage in "hostilities" and use "force." ${ }^{135}$ His language over-

\footnotetext{
${ }^{123}$ Samuel Purviance, Jr., to John Adams (Sept 18, 1776), in Taylor, ed, 5 Papers of John Adams at 31, 31-32 (cited in note 53). Benjamin Franklin, also in Congress, received similar pleas. See Elizabeth Hubbart Partridge to Benjamin Franklin (Sept 17, 1776), in Willcox, ed, 22 Papers of Benjamin Franklin at 610 (cited in note 65); id at 657-58 (testimony in prize case).

${ }^{134}$ See note 28.

${ }^{135}$ Lobel, 50 U Miami L Rev at 67 (cited in note 3); Lobel, $134 \mathrm{U}$ Pa L Rev at 1040, 1044, 1045 (cited in note 3). See text accompanying notes 22-24 for his emphasis on loose terms at the Founding.
} 
looks how privateers fought the enemy and how often; whether they even intended to fight; what sort of enemy they fought; how well or poorly they functioned with or in place of true military vessels; how, if at all, they were supervised; and, most importantly, how their voyages were funded. Only after skirting such details can one declare that the Marque and Reprisal Clause "unambiguously" covers all undeclared warfare. ${ }^{136}$ As an effort at historical induction, this lacks the precision that is necessary given the shifting meaning of letters of marque and reprisal prior to the Founding. ${ }^{137}$

Their second mistake, made possible by the unwarranted generalization of the first, is to construe the Marque and Reprisal Clause too broadly to include modern military incidents that it cannot contain. For example, Lobel construes the Marque and Reprisal Clause to apply to the CIA's covert wars, use of "proxy" armies, and paramilitary operations, particularly actions in Nicaragua, Afghanistan, and Cambodia under the Reagan Doctrine. ${ }^{138}$ Yet such an interpretation overlooks numerous crucial differences from privateering. Those doing the CIA's fighting were pursuing purely military goals-usually toppling Communist governments-rather than commercial ones. They actually wanted to fight. Their skill at fighting greatly exceeded the privateers'. Federal funds, which the privateers never received, were their life support. And federal officials supervised their efforts. ${ }^{139}$ These objections apply with even more force to fighting by United States troops, as in Grenada and Panama.

\footnotetext{
${ }^{126}$ Ely, War and Responsibility at 74 (cited in note 22). Lofgren at least offered his conclusion tentatively, even if those who rely on him do not. 81 Yale L J at 697 (cited in note 9).

${ }^{137} \mathrm{~A}$ member of Congress in 1810 attacked the same error when he criticized his colleague's sloppy appeal to the practice of the British Parliament: "It is well known that the powers of the House of Commons have been very different at different times. . . . At which of these periods daes the gentleman apply the proceedings of the House of Commons as a model for this House?" Speech of Rep Findley (Apr 3, 1810), in 21 Annals of the Congress of the United States 1735 (Gales \& Seaton 1853). On the changing meaning of letters of marque and reprisal, see text accompanying notes 14-15.

${ }^{123}$ Lobel, $134 \mathrm{U} \mathrm{Pa} \mathrm{L}$ Rev at 1049-52 (cited in note 3). See also id at 1084 (discussing paramilitary operations in Guatemala, Cuba, and Nicaragua).

${ }^{159}$ Thus Lobel defines covert activity as including "financial support and assistance to foreign political parties ... and the direction of paramilitary operations designed to overthrow or support a foreign regime." He emphasizes the CIA's role in "organiz[ing]" such activities and notes President Reagan's goal of "underwriting anti-Communist insurgency." Id at 1049-51.
} 


\section{B. The Marque and Reprisal Clause and Congress's Power of the Purse}

More generally, scholars overlook the key elements of letters of marque and reprisal and thereby guarantee misinterpretation. A careful analysis of the relevant history, combined with an appreciation of the importance of Congress's power of the purse, leads to the conclusion that the essential feature of letters of marque and reprisal in the American Revolution was financial independence: the income from seizure of prize (the overriding goal), the lack of congressional funding, and the ability to win title to the prize in the court proceedings.

Put differently, the power of the purse is Congress's chief power over war, yet the power cannot control privateers and letters of marque. The Marque and Reprisal Clause corrects this deficiency. Its most likely purpose was to plug a hole in Congress's power of the purse. This is a hole that does not exist in any of the examples of modern military activities that scholars attempt to fit under the Clause. The executive actions they decry often involve modern-day mercenaries, yet such "contracting out" of war, common in the eighteenth century, ${ }^{140}$ is not at all what letters of marque and reprisal of the Revolution involved or what the Clause was intended to address. Such contracts are not free for the government; privateering is. Scholars increasingly acknowledge the importance of Congress's power of the purse in war powers, ${ }^{141}$ although such awareness is hardly new. James Madi-

${ }^{10}$ See, for example, Ely, War and Responsibility at 74 (cited in note 22). See also Stern and Halperin, Introduction, in Stern and Halperin, eds, Power to Go to War at 7 (cited in note 18) (The Marque and Reprisal Clause "is the historical antecedent to what is now overt/covert lethal support of foreign military forces.") (emphasis added).

${ }^{111}$ The three most thorough recent examples are John Yoo, 84 Cal L Rev at 296-300, 303, 305 (cited in note 13); Peter Raven-Hansen and William C. Banks, From Vietnam to Desert Shield: The Commander in Chiefs Spending Power, 81 Iowa L Rev 79 (1995); and William C. Banks and Peter Raven-Hansen, National Security Law and the Power of the Purse (Oxford 1994). See also, for example, Spiro, $37 \mathrm{Wm} \&$ Mary L Rev at 738 (cited in note 1) ("The primary lever for the new congressional boldness is the appropriations power."); Kate Stith, Congress' Power of the Purse, 97 Yale L J 1343 (1988); J. Gregory Sidak, The President's Power of the Purse, 1989 Duke L J 1162; Jeffrey A. Meyer, Congressional Control of Foreign Assistance, 13 Yale J Intl L 69 (1988).

Even those who argue for congressional supremacy on grounds of the war power clauses note the importance of the power of the purse. See, for example, Michael J. Glennon, Strengthening the War Powers Resolution: The Case for Purse-Strings Restrictions, 60 Minn L Rev 1, 29 (1975) (noting that the Supreme Court has never struck down any congressional restrictions on the executive branch through its power of the purse); Ely, War and Responsibility at 198 n 56 ("[T] could be ended by congressional withdrawal of funding."), 29 (finding that the power of the purse is inadequate for ending a war) (cited in note 22). Lobel argues that the power of the purse is inadequate when the executive hides its activities from Congress, and that cutting off funding is institutionally difficult for Congress. Lobel, $134 \mathrm{U} \mathrm{Pa} \mathrm{L}$ Rev at 1079- 
son called the power of the purse the "most complete and effectual weapon with which any constitution can arm the immediate representatives of the people, ${ }^{, 142}$ and credited the power with the House of Commons's "continual triumph" over the monarchy. But this mighty power evaporates if the President may act independently of legislative funds, as he could if he, like the British King, issued letters of marque and reprisal. Were it not for the Marque and Reprisal Clause, the power to issue the letters would likely rest with the President alone, who could credibly invoke British history to support his prerogative and who would have no need of Congress's money. ${ }^{143}$

One can thus answer Professor Lobel's reductio ad absurdum to those who would urge a limited "technical" reading of the Clause. He asks: "Why would the framers give Congress power to authorize minor uses of force by private parties, if they did not also mean for Congress to have power to authorize major use of American armed forces . . ? ?144 The answer is that, without explicit power over letters of marque and reprisal, Congress would have no power over them, given privateers' financial independence. ${ }^{145}$ But CIA covert activities do not raise this concern, especially given Lobel's emphasis on the CIA's organizing and funding role. ${ }^{146}$ Actions involving federally funded American forces, such as the invasions of Grenada and Panama and the bombing of Libya, no matter how "little" or brief, fall even farther from the Clause. ${ }^{147}$

If the Clause were to have any relevance to modern warfare, it would have to be in areas where the President evades the power of the purse, as he attempted to do in funding the Contras and Operation Desert Shield. ${ }^{148}$ When the President finds ways to

80 \& n 204 (cited in note 3). Yoo answers the latter point: "[A] failure of political will should not be confused with a constitutional defect." Yoo, 84 Cal L Rev at 299 (cited in note 13).

${ }^{12}$ Federalist 58 (Madison), in Rossiter, ed, The Federalist Papers at 356, 359 (cited in note 27).

${ }^{143}$ On Great Britain and the King, see Sofaer, War, Foreign Affairs, and Constitutional Power at 6-10 (cited in note 22).

${ }^{14}$ Lobel, $50 \mathrm{U}$ Miami L Rev at 70 (cited in note 3). This is question-begging of a high order: while the Framers may have intended what Lobel argues regarding congressional war power, this does not tell us which clause might grant such power.

${ }^{145}$ Congress could, of course, use indirect means to control this, such as restricting funding in some other area.

${ }^{146}$ See notes 138-39.

${ }^{147}$ These are three of Lobel's examples. Lobel, $50 \mathrm{U}$ Miami L Rev at 76 (cited in note 3).

${ }^{143}$ While not invoking the Marque and Reprisal Clause, Congress clearly saw this problem during the Iran-Contra affair: "By circumventing Congress's power of the purse through third-country and private contributions to the Contras, the Administration un- 
fight wars without congressional money, leaving the power of the purse powerless, the principle of the Marque and Reprisal Clause is violated. ${ }^{149}$ Were he to authorize a self-financed private party to conduct hostilities on behalf of the United States, the Marque and Reprisal Clause would protest even more, particularly if the party somehow profited from the effort. ${ }^{150}$

\section{CONCLUSION}

Modern scholars are demanding too much from the Marque and Reprisal Clause. Their efforts to treat the Clause as encompassing all military actions short of declared war, and then to join it with the Declare War Clause to require Congress to approve all presidential uses of force, are unwarranted at least to the extent that they rely on the Marque and Reprisal Clause. The historical arguments supporting their reading of the Clause's original meaning are useful but inadequate since they ignore practice in the American Revolution. Analysis of such practice leads to a narrower reading of the Clause, one that emphasizes the unique and pervasive financial aspects of letters of marque and reprisal that allowed their holders to operate independently of Congress's power of the purse. This historical view reveals the Marque and Reprisal Clause to have no bearing on typical CIA covert activity, much less the escapades of American troops.

dermined a cardinal principle of the Constitution." Report of the Congressional Committees Investigating the Iran-Contra Affair, S Rep No 100-216, HR Rep No 100-433, 100th Cong, 1st Sess 16 (1987). See also id at 413-14 (criticizing Oliver North's efforts to set up a "nominally private entity" to filter funds for the Contras and avoid the appropriations process). Allegations that the CIA entered the drug business to finance the Contras implicate the same concerns. See Charles Lane, Just Say No, The New Republic 4, 4 (Nov 25, 1996) (discussing and dismissing such allegations).

Under a law allowing the executive to determine the use of "gifts" for national defense, President Bush attempted to fund Desert Shield with billions of dollars donated by foreign nations. Congress then restricted the use of these gifts, although it eventually passed supplemental appropriations. See Raven-Hansen and Banks, 81 Iowa L Rev at 8692 (cited in note 141).

${ }^{19}$ Compare the similar sentiment of Raven-Hansen and Banks: "To the extent that third-party funding affords the Commander in Chief the means to fund a military operation explicitly opposed by Congress, it undermines at least the spirit, if not the letter of the Appropriations Clause." 81 Iowa L Rev at 134 (cited in note 141). While RavenHansen and Banks accept Lofgren's and Lobel's view of the Marque and Reprisal Clause and do not emphasize the link between the Clause and the power of the purse, they properly understand Congress's Boland amendments of the 1980s, restricting funding for the Contras, as "premised on the same structural allocation of power" as the Marque and Reprisal Clause. Banks and Raven-Hansen, National Security Law at 151 (cited in note 141).

${ }^{15}$ A privately funded airlift into hostile territory would be an example, particularly if those conducting it funded their mission with sales from the airlift. For a similar example, see Raven-Hansen and Banks, 81 Iowa L Rev at 100-01 \& n 140 (cited in note 141). 


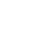

